\title{
Study to Detect Seed Borne Mycoflora Associated with Chickpea (Cicer aeritinum L.) Seeds
}

\author{
Ramesh Amule $^{1 *}$, Ranu Singh ${ }^{1}$, Om Gupta $^{2}$, Neelima Raipuriya ${ }^{1}$ and P.K. Gupta ${ }^{2}$ \\ ${ }^{1}$ Rani Durgawati Vishvavidyala, Jabalpur M.P, India \\ ${ }^{2}$ Jawaharlal Nehru Krishi Vishwa Vidyalaya, Jabalpur M.P, India \\ *Corresponding author
}

\section{A B S T R A C T}

\section{Keywords}

Chickpea, Seed borne myco-flora, Standard blotter paper, Agar plate method

Article Info

Accepted:

07 October 2019 Available Online: 10 November 2019
Madhya Pradesh is the largest producer of chickpea (Cicer arietinum L.) in India. A number of abiotic and biotic factors are responsible for its yield gaps of being below its potential. Therefore an study was conducted during two consecutive years 2015-16 and 2016-17 at Department of Plant Pathology, JNKVV, Jabalpur to detect seed borne mycoflora associated with Chickpea seeds by different methods of seed testing. During the study, total 30 varieties of chickpea viz., JG 130, JG 63, JG 16, JG 315, JG 11, JG 74, JG 322, JG 412, JG 226, JG 6, JG 14, JG 62, JG 218, Pragati, Uday, Vijay, Radhey, KJD 1168 (Alok), Avrodhi, JAKI 9218, BGD 72, BGD 128, BGD 1057, BGD 1058, Digvijay, Samrat, Vihar, GNG 1946, GNG 1845 and K 850 were collected and examined from different location of Madhya Pradesh by standard protocols of Standard blotter paper, 2,4D blotter, Agar plate, Deep freeze, Paper towel and Seedling symptoms test method. The revealed that, the Standard Blotter Paper Method was found best method (110.0\%) for testing of seed associated mycoflora followed by Agar Plate Method (103.2\%), Deep Freeze Method (90.8\%), Paper towel method $(80.1 \%)$, Seedling symptoms test $(75.3 \%)$ and 2, 4-D Method (56.4\%). It was also concluded a total eight genera of fungi viz. Fusarium oxysporum, Rhizoctonia bataticola, Alternaria alternata, Aspergillus flavus, Aspergillus niger, Curvularia lunata, Rhizopus spp. and Penicillium spp. were reported in different varieties of chickpea. Among them Aspergillus niger, Aspergillus flavus, Rhizopus spp. and Fusarium oxysporum were predominant to all seed samples.

\section{Introduction}

In Indian Agriculture pulses play an important role not only from economical point of view but also due to their nutritional value. Among all the pulses chickpea is the most important one being rich sources of protein (21\%), carbohydrates $(61.57 \%)$ and vitamin $\mathrm{C}$.
Chickpea producing states in India are Madhya Pradesh, Uttar Pradesh, Rajasthan, Maharashtra and Andhra Pradesh. Madhya Pradesh contributes 40.96 percent of the total production of chickpea in the country. In Madhya Pradesh it ranks $1^{\text {st }}$ in both area (3.59 $\mathrm{m}$. ha.) and production $(4.6 \mathrm{~m}$. tones) and the average productivity is estimated $1280 \mathrm{~kg}$./ha. 
Agri. Statistics at a glance, (2017-18). The number of diseases recorded on the chickpea has been increased and those which were formally of little importance have now become more significant.

There are more than 50 pathogens known to attack chickpea of which about 40 are of economic important. Many factors is involved in reducing chickpea seed quality but a combination of susceptibility to pathogenic fungi, environmental condition that favour disease development and field deterioration of seed. Moreover chickpea seeds are rich in protein contain and therefore easily infected by several field and storage fungi which not only affect seed quality but also emergence in field.

Detected several fungal species belonging to many genera from cultivars of chickpea seedborne fungi of chickpea have been also reported by various workers from time to time (Rathod et al., 2012 and Narayan et al., 2013).

Hence the present study on detection of seedborne myco-flora of chickpea was conducted to know the seed mycoflora associated with the chickpea seeds from different locations of Madhya Pradesh.

\section{Materials and Methods}

\section{Collection of seed samples of chickpea}

Seeds of thirty chickpea cultivar were collected from farmer's fields of different agro climatic zones of Madhya Pradesh and All India Co-ordinated Research Project on Chickpea, Department of Plant Breeding \& Genetics, JNKVV, Jabalpur (M.P.) viz., JG 130, JG 63, JG 16, JG 315, JG 11, JG 74, JG 322, JG 412, JG 226, JG 6, JG 14, JG 62, JG 218, Pragati, Uday, Vijay, Radhey, KJD 1168 (Alok), Avrodhi, JAKI 9218, BGD 72, BGD 128, BGD 1057, BGD 1058, Digvijay,
Samrat, Vihar, GNG 1946, GNG 1845 and K 850.

\section{Blotter paper method}

Standard blotter method was used for the detection of seed borne fungi of chickpea. The 100 seeds of each variety were sown on three layers of pre-soaked moist blotter paper having $9 \mathrm{~cm}$ diameter. In each plate 5 seed were arranged, 4 seeds in the outer ring and one in the center of petri plates.

\section{Agar plate method}

Agar plate method is preferred mostly in plant pathological studies as it provides nutrients rich substrate for development of mycelial growth and sporulation of pathogen on seed, particularly for slow growing fungi, PDA medium was autoclaved at $1.04 \mathrm{~kg} / \mathrm{cm} 2$ for 15 minute and warm medium approximately 15 $\mathrm{ml}$ per plate was poured. On solidification 100 seeds were plated, each plate containing 5 seeds.

\section{Deep freeze method}

This method allows better growth of certain fungi as the imbibed seeds on moist blotters are killed by deep freezing and the enclosed nutrients in seed are utilized by fungi. One hundred seeds were plated as in blotter method and incubated for $24 \mathrm{hr}$ at room temperature $\left(27 \pm 2^{\circ} \mathrm{C}\right)$ then the plated seeds were deep frozen at $-20^{\circ} \mathrm{C}$ for $24 \mathrm{hr}$.

\section{2, 4 - D Method}

2,4-D, is a herbicide retards seed germination and seedlings growth due to which the seeds are not displaced and the examination of fungi becomes easy, the blotter were soaked in 0.1 per cent 2,4-D suspension and then placed in plates. Two hundred seeds were incubated for seven days as in blotter method. The plated 
seeds were then incubated at $27 \pm 20^{\circ} \mathrm{C}$, under alternate cycle of $12 \mathrm{hr}$ light and $12 \mathrm{hr}$ darkness for seven days by using two $40 \mathrm{~W}$ white fluorescent tubes. After seven days of incubation, seeds were examined under stereoscopic microscope by using a magnification of $6 \mathrm{X}$ to $50 \mathrm{X}$.

Research microscope was also used to confirm the identification of fungi based on morphological characters given in standard mycological books.

\section{Rolled paper towel method}

Randomly selected 100 seeds were placed on two layers of moist germination papers, which will be placed on a polythene paper, at ten seeds per row. These seeds will be were covered with another moist germination paper and rolled carefully to avoid any excess pressure on seeds. The rolled towel papers will be kept in slanting position along the wall of laboratory tables and incubated at $26 \pm 2^{\circ} \mathrm{Cfor}$ 7 days. The first count of germination was taken on $4^{\text {th }}$ day and final count of $10^{\text {th }}$ day. Morphologically normal seedlings were examined with stereo binocular microscope.

\section{Seedling symptoms test}

This method is developed by Khare, Mathur and Neergaard in 1977. $10 \mathrm{ml}$ water agar is taken in each $16 \mathrm{~mm}$ diameter rimless test tube, sterilized and solidified with slight slant. One seed is sown in each test tube.

The tubes are placed for incubation at $20^{\circ} \mathrm{C}$ under artificial day light tubes, 12/12 h cycle. To retain moisture they are covered individually or in groups by a plastic sheet or aluminium foil which is removed when the seedlings have reached the cover. Seedlings are examined after 14 days for the typical symptoms of disease in the coleoptiles. The symptoms can be easily studied being visible on roots as well as on green parts.

\section{Results and Discussion}

Table 1 showed that the result of comparative performance of various seed health detection methods employed in present study. The results revealed that, all the six seed health detection methods attempted were found to be efficient in detecting various myco-flora associated with the seeds of thirty chickpea varieties. However, higher percentages of the major eight seedborne fungi were evidenced by the seed health detection methods standard blotter paper method was found best method (110.0) for testing of seed associated fungi followed by Agar plate method (103.2 \%), Deep freeze method (90.8\%), Paper towel method (80.1\%), Seedling symptoms test $(75.3 \%)$ and 2, 4 - D blotter method. These findings are inconformity with findings of Khan et al., (1988), Arya et al., (2004) and Warude et al., (2016). Among all the method tested Aspergillus niger was observed maximum $(30.6 \%)$ in standard blotter paper followed by Agar plate (26.9\%), Deep freeze $(24.9 \%)$ and paper towel (24.5) was found predominant in all the thirty varieties of chickpea. Aspergillus flavus was observed maximum in standard blotter $(23.3 \%)$ followed by agar plate $(20.8 \%)$ while minimum was recorded in 2,4-D blotter $(11.7 \%)$. In all eight mycoflora associated with chickpea seeds Rhizopus spp. was noticed maximum in standard blotter (22.4\%) while minimum was recorded in 2,4-D blotter (10.0\%) followed by paper towel (14.4\%), seedling symptoms (16.8\%). In agar plate detection method Fusarium oxysporum was observed maximum 20.0\% followed by standard blotter $19.6 \%$ and Deep freeze $19.5 \%$. Minimum association of Rhizoctonia bataticola was recorded in seedling symptoms method while maximum was observed in agar plate. 
Table.1 Comparative evaluation of different detection method for association of myco-flora in chickpea seeds

\begin{tabular}{|c|c|c|c|c|c|c|c|}
\hline \multirow{2}{*}{$\begin{array}{c}\text { S. } \\
\text { No. }\end{array}$} & \multirow[t]{2}{*}{ Fungi } & \multicolumn{6}{|c|}{ Per cent myco-flora association on chickpea seed } \\
\hline & & $\begin{array}{l}\text { Standard } \\
\text { blotter } \\
\text { paper } \\
\text { method }\end{array}$ & $\begin{array}{c}\text { 2,4-D } \\
\text { blotter } \\
\text { method }\end{array}$ & $\begin{array}{c}\text { Agar } \\
\text { plate } \\
\text { method }\end{array}$ & $\begin{array}{c}\text { Deep } \\
\text { freeze } \\
\text { method }\end{array}$ & $\begin{array}{c}\text { Paper } \\
\text { towel } \\
\text { method }\end{array}$ & $\begin{array}{c}\text { Seedling } \\
\text { symptoms } \\
\text { test }\end{array}$ \\
\hline 1. & Fusarium oxysporum & 19.6 & 12.0 & 20.0 & 19.5 & 16.6 & 14.1 \\
\hline 2. & Rhizoctonia bataticola & 1.8 & 1.7 & 2.8 & 1.6 & 1.8 & 1.5 \\
\hline 3. & Alternaria alternate & 5.1 & 4.0 & 4.4 & 3.5 & 3.8 & 3.2 \\
\hline 4. & Aspergillus flavus & 23.3 & 11.7 & 20.8 & 17.6 & 12.2 & 12.0 \\
\hline 5. & Aspergillus niger & 30.6 & 14.0 & 26.9 & 24.9 & 24.5 & 23.3 \\
\hline 6. & Curvularia lunata & 1.7 & 1.3 & 1.4 & 1.4 & 1.7 & 1.4 \\
\hline 7. & Rhizopus spp. & 22.4 & 10.0 & 18.7 & 17.6 & 14.4 & 16.8 \\
\hline 8. & Penicillium spp. & 5.5 & 1.7 & 8.2 & 4.7 & 5.1 & 3.0 \\
\hline & Total fungi & 110.0 & 56.4 & 103.2 & 90.8 & 80.1 & 75.3 \\
\hline
\end{tabular}

In standard blotter Alternaria alternata (5.1\%) was observed maximum. Curvularia lunata recorded ranged from 1.3 to $1.7 \%$ in 2,4-D blotter and standard blotter, respectively. In agar plate method Penicillium spp. was observed maximum $(8.2 \%)$ followed by 5.5 $\%$ in standard blotter method. In present study, among six seed health detection methods attempted. The most efficient were Standard blotter paper and Agar plate methods.

These methods of seed health detection were also reported as most efficient and reliable for detection of various mycoflora associated with the seeds of soybean, sesame, sunflower, niger, chickpea, pigeonpea etc, by several earlier workers (Mandhare et al., 2009). Sontakke and Hedawoo (2014) and Patil et al., (2018).

It was concluded from the present study, amongst the six method used for testing of thirty chickpea varieties, the Standard Blotter Paper Method was found best method (110.0\%) for testing of seed associated mycoflora followed by Agar Plate Method (103.2\%), Deep Freeze Method (90.8\%), Paper towel method (80.1\%), Seedling symptoms test $(75.3 \%)$ and 2, 4-D Method (56.4\%). It was also concluded a total eight genera of fungi viz. Fusarium oxysporum, Rhizoctonia bataticola, Alternaria alternata, Aspergillus flavus, Aspergillus niger, Curvularia lunata, Rhizopus spp. and Penicillium spp. were reported in different varieties of chickpea.

Among them Aspergillus niger, Aspergillus flavus, Rhizopus spp. and Fusarium oxysporum were predominant to all seed samples.

\section{Acknowledgement}

The authors are thankful to the Head, Department of Plant Pathology and Department of Plant Breeding \& Genetics, JNKVV, Jabalpur (M.P.) for providing the necessary facilities to carry out the research work.

\section{References}

Anonymous (2018). Agricultural Statistics at a glance. Department of Agricultural Govt. of India, New Delhi 
Arya, V.K., Vishonavat, K. and Negi, H. (2004). Detection, location and transmission of seed-borne inoculums of Macrophomina phaseolina in charcoal rot in soybean. J. Mycol. Pl Pathol., 34: 233-237

Islam SMM, Masum MMI, Fakir MGA (2009). Prevalence of seed borne fungi in sorghum of different location of Bangladesh. Scientific Research and Essay. 4(3): 175-179

Khan, S.J., Khozada, A.K., Sultana, N. and Aslam, M. (1988). Evaluation of seed health testing technique for assessment of seed- borne mycoflora of rice. Pakistan J. Agric, Res., 9(4): 502-505

Mandhare, V. K., Gawade, S. B. and Suryawanshi, A. V. (2009). Detection and transmission of seedborne infection Macrophomina phaseolina causing char coal rot in soybean. $J . P l$. Dis. Sci., 4(1): 130-131

Narayan.M., Ghangaokars, and Ayodhya, D.,
Kshirsagar (2013). Study of seed borne fungi of different legumes an International peer reviewed journal. 2: ISSN 2319-4731.

Patil, A. C., Suryawanshi A. P., Anbhule, K. A., Raner, R. B. Hurule, S. S. (2018). Detection of sunflower seed borne mycoflora and their effect on Seed and Seedling parameters. Int. J. Curr. Microbiol. App. Sci. pp 6: 2509-2514

Rathod, L.R., Jadhav, S.K., Mane, S.K., Mule, S.M., Deshmukh (2012). Seed borne Mycoflora of Legume seeds ISSN 09762612, 13(1): 530-532

Sontakke, N.R. and G.B. Hedawoo (2014). Mycoflora associated with seeds of chickpea. International Journal of Life Science, Special Issue A2: 27-30.

Warude, S.N., S.S. Mane and G. K. Giri (2016). Detection of seed - borne myco-flora associated with chickpea. International Journal of Pure and Applied Biosciences, 4: 309-315.

\section{How to cite this article:}

Ramesh Amule, Ranu Singh, Om Gupta, Neelima Raipuriya and Gupta, P. K. 2019. Study to Detect Seed Borne Mycoflora Associated with Chickpea (Cicer aeritinum L.) Seeds. Int.J.Curr.Microbiol.App.Sci. 8(11): 424-428. doi: https://doi.org/10.20546/ijcmas.2019.811.052 